Golden Age: Journal of Early Childhood Education, Volume 4 Nomor 01 (Juni 2020)

ISSN 2549-8371 | E-ISSN 2580-5843

Karennina Cahya, Ruli Hafidah, Retnu Sipparamita / Improved Ability to Listen to Children of Group A in Al A'raaf Islamic Kindergarten Through Audio Visual Media

\title{
Improved Ability to Listen to Children of Group A in AI A'raaf Islamic Kindergarten Through Audio-Visual Media
}

\author{
KARENNINA CAHYA ', RULI HAFIDAH 2, RETNU SIPPARAMITA 3 \\ Early Childhood Education Teacher Education Study Program \\ Faculty of Teacher Training and Education Sebelas Maret University Surakarta \\ Email: karenninacahya@gmail.com, rulihafidah@staff.uns.ac.id, famitamitasip@gmail.com \\ Article Received: 15 December 2020 \\ Published Article: 01 June 2020 \\ DOI: https://doi.org/10.29313/ga:jpaud.v4i1.5424
}

\begin{abstract}
This study aims to improve listening skills through audio-visual media in Children of group A in Al A'raaf Islamic Kindergarten Gentan, Baki, Sukoharjo. The subjects were children of 4-5 years age group TK Islam Al A'raaf kindergarten amounted to 25 children. Methods of data collection are done through observation, interview, and documentation. The data analysis technique performed a qualitative descriptive. Based on the discussion results, it can be concluded that listening skills in children can be improved by audiovisual with a display of various types of stories. Children show improvement in answering simple questions given by the teacher regarding the contents of the story being aired and an increase in the average results of children's listening abilities. Students' initial average listening skills were $9 \%$, which increased to $71 \%$ in the second meeting.
\end{abstract}

Keywords: Listening Skills; Audio-Visual Media; Group A Kindergarten.

\begin{abstract}
Abstrak
Penelitian ini bertujuan untuk mengetahui kemampuan menyimak pada anak melalui media audio-visual pada anak Kelompok A di TK Islam Al A'raaf Gentan, Baki, Sukoharjo. Subjek penelitian ini adalah anak kelompok usia 4-5 tahun di TK Islam Al A'raaf yang berjumlah 25 anak. Metode pengumpulan data dilakukan melalui observasi, wawancara, dan dokumentasi. Teknik analisis data dilakukan secara deskriptif kualitatif. Berdasarkan hasil pembahasan dapat disimpulkan bahwa kemampuan menyimak pada anak dapat ditingkatkan melalui media audio-visual dengan tayangan berbagai jenis cerita. Anak menunjukkan peningkatan dalam menjawab pertanyaan sederhana yang di berikan guru mengenai isi cerita yang ditayangkan serta peningkatan hasil ratarata kemampuan menyimak anak. Peningkatan rata-rata kemampuan menyimak anak pada kondisi awal sebesar 9\% meningkat menjadi $71 \%$ di pertemuan kedua.
\end{abstract}

Kata Kunci: Kemampuan Menyimak; Media Audio-Visual; Anak Kelompok A. 
Golden Age: Journal of Early Childhood Education, Volume 4 Nomor 01 (Juni 2020)

ISSN 2549-8371 | E-ISSN 2580-5843

Karennina Cahya, Ruli Hafidah, Retnu Sipparamita / Improved Ability to Listen to Children of Group A in Al A'raaf Islamic Kindergarten Through Audio Visual Media

\section{INTRODUCTION}

Language development is one aspect that needs to be developed in early childhood because language is a means to communicate so that children can express their ideas, thoughts, and feelings to others (Prasitnok et al., 2017).

(Tarigan, 2008) states language skills cover four aspects: listening, speaking, reading, and writing. . From these four aspects, the listening ability is the earliest before children can speak, read, and write. Listening is a process of listening to verbal symbols with full attention, understanding, appreciation, and interpretation to obtain information, capture content or messages, and understand the meaning of communication that has been delivered by the speaker through spoken speech or language (Prasitnok et al., 2017).

Listening is an early language skill that is mastered by humans. Listening skills are the basis for other language skills. Listening skills will be the basis for developing other language skills because listening skills are the essential skills that a person must possess before possessing speaking, reading, and writing skills (Suhartati, 2013); listening to a language skill that has been held since man was born. However, it is often difficult to understand the verbal information conveyed by someone. Most of our time is to listen/listen. Either listening / listening to stories, music, news, or other information (Utami et al., 2013).

The ability to listen needs to be developed by children so that they can understand their environment. In order for children to learn, they must receive and process information. At the age of kindergarten, children are still limited in understanding language skills. Learning children to listen to others will increase the opportunity to learn the language and new ideas. This is also one of the most challenging skills to teach to children aged 3-5 years, who are not very interested in listening to the people around them.

According to Tarigan in (Utami et al., 2013) the purpose of listening is to: (1) obtain information that has a relationship with the profession; (2) enhance the effectiveness of communication; (3) collecting data to make decisions; (4) giving the right response, (4) gaining knowledge directly or through radio or television; (5) enjoy the beauty of audio that is heard or exhibited; (6) evaluates the results of the hearing, and (7) appreciates hearing materials so they can enjoy and appreciate them.

According to Gagne (Setyawan, 2016), the media are various types of components in the student environment that can stimulate learning. Media based on delivering and receiving is divided into three: audio media, visual media, and audio-visual media. Audio or listening media is media that can convey messages through voices or sounds that are played. This media relies heavily on the hearing ability of its users. This sound element has components of language, music, and sound effects combined with strengthening the message content. Audio media is also very flexible, relatively inexpensive, practical, and short and easy to carry. Therefore teachers and parents can use this media as a tool or facility to support children's language development (Setyawan, 2016).

One of the types of instructional media that can enhance the listening skills of children is audiovisual media. Audio-visual media is a medium for delivering audio (sound) and visual (picture) characteristics. This type of media has a better ability because it covers both of these characteristics. Furthermore, audio-visual media is divided into two, namely: a) Audio-visual still, namely media that displays sound and still images such as sound frame films, sound frame films, and sound prints; b) audio-visual motion, which is media that can display sound elements and moving images such as sound films and video cassettes. Other divisions of audio-visual media are a) pure audio-visual, i.e., both the sound element and the image comes from one source such as a video cassette film; b) audio-visual is not pure, i.e., the sound elements and picture elements come from different sources, for example, sound frame films whose picture elements are from the projector slide and the sound elements are sourced from a tape recorder (Haryoko, 2009).

Learning media can help effectiveness in the learning process, delivery of messages, and lesson content. However, teachers often ignore the use of media, whereas using learning media, especially audio-visual media, it can foster children's interest in learning so that children easily capture the 
Golden Age: Journal of Early Childhood Education, Volume 04 Nomor 01 (Juni 2020)

ISSN 2549-8371 | E-ISSN 2580-5843

Karennina Cahya, Ruli Hafidah, Retnu Sipparamita / Improved Ability to Listen to Children of Group A in Al A'raaf Islamic Kindergarten Through Audio Visual Media

contents of the story displayed. Steps in learning to use audio-visual media, prepare laptops, sound, cables, and videos to be shown, pay attention to the student's sitting position in a comfortable condition, and when they invite students to watch the video, the teacher conveys the learning objectives and learning techniques. The students are ready to watch the video and be given a followup in the form of questions related to the video's contents.

The use of audio-visual animation media in learning to listen to children's stories is expected to increase students' curiosity and interest and motivate learning. If students are motivated, students will follow the learning as well and as much as possible. Thus, it is expected to improve children's story listening skills that can be identified from student learning outcomes and changes in student's attitudes towards a positive direction (Suhartati, 2013).

Group A children are children who are vulnerable at the age of 4-5 years. Based on (MENTERI PENDIDIKAN DAN KEBUDAYAAN REPUBLIK INDONESIA, 2014) concerning the Standards of Achievement in Child Development, aged 4-5 years are as follows :

a. Understanding Language

$\checkmark$ Listen to the words of others (mother tongue or another language)

$\checkmark$ Understand the two commands given together

$\checkmark$ Understand the story being read

$\checkmark$ Get to know vocabulary about adjectives (naughty, stingy, kind, brave, good, bad, etc.)

$\checkmark$ Listen to and distinguish sounds in Indonesian (for example, sounds and speech must be the same)

b. Reveal Language

$\checkmark$ Repeat simple sentences

$\checkmark$ Ask the correct sentence

$\checkmark$ Answering questions according to questions

$\checkmark$ Express feelings with words (good, happy, naughty, stingy, kind, brave, good, bad, etc.)

$\checkmark$ Mention known words $\checkmark$ opinions to others

$\checkmark$ State the reason for something desired or disagreement

$\checkmark$ Tells backstories/tales that have been heard

$\checkmark$ Enrich vocabulary

$\checkmark$ Participate in conversations

c. Literacy

$\checkmark$ Get to know the symbols

$\checkmark$ Recognizing the sounds of animals or objects that are around it

$\checkmark$ Make meaningful scribbles

$\checkmark$ Mimic (write and pronounce) the letters $A Z$

Based on preliminary observations made at Al A'raaf Islamic Kindergarten in group A children, listening activities in group A children were not fully maximized. Children have not realized the critical role of listening to learning in school. This can be seen when listening activities occur with audiovisual media; most of the children do not pay attention to video views. This happens because the child's lack of interest in these types of video shows causes boredom. The type of story that will be shown should be able to invite the attention of children so that listening to children can be optimal. From this problem, the writer took the title "Improving the Ability to Listen to Children of Group A in Al A'raaf Islamic Kindergarten Through AudioVisual Media."

\section{RESEARCH METHODOLOGY}

The method used in this research is a descriptive method of case study analysis with a qualitative approach. Qualitative research is research that generates and processes descriptive data nature, such as the transcription of interviews, field notes, images, recordings, and others. The type of research the writer uses is descriptive qualitative research. Qualitative research methods are intended for research that observes cases. Thus the process of data collection and analysis is also crucial. Findings kualitati f directed to produce improvement - improving the quality of work and basically could also be beneficial for 
academic interest. According to Taylor and Bogdan, 1984 in (Ivanovich Agusta, 2014), data qualitative descriptive form, the form of words spoken or written about human behavior, can be observed.

The purpose of qualitative research is to find out actuality, social reality, and human perception through their recognition that may not be revealed by highlighting formal measurements or research questions that have been prepared in advance (Prof. Dr. H. Warul Walidin AK. et al., 2015). In qualitative research, the most popular data collection techniques are used more in observation, interviews, and documentation. To get data or information on the problem under study, the authors use the following collection techniques:

1. Observation

Using the observation method, the most effective way is to complete it with the format or observation blank as an instrument. The format arranged contains items about events or behaviors that describe what will happen. A scientific method of observation is interpreted as an observation of systematic recording of the phenomena under investigation (Lexi \& M.A., 2010). Observations were made on a non-participant basis, in which the researcher acted only as an observer of the phenomenon under study. Observations were made directly to get a complete picture related to the focus of research. The observations are arranged in a field note. Fill in the field notes in the form of recurring events, temporal, interaction, and interpretation.

2. In-depth interview

An interview is a conversation with a specific purpose. The conversation was carried out by two parties, namely the interviewer who raised the question and the interviewer who answered that question (Lexi \& M.A., 2010). We conducted interviews with question and answer dialogues with class A teachers in Al A'raaf Islamic Kindergarten.

3. Documentation Study

According to Sugiyono (2007: 329), in (Nilamsari, 2014), documents are records of events that have passed in the form of writings, drawings, or monumental works of a person. Documentation study is a way to collect data sources that are used to complement research, both in the form of written sources, films, pictures (photographs), and monumental works, all of which provide information for the research process.

\section{RESULTS AND DISCUSSION \\ Results}

This research was conducted at Al A'raaf Gentan Islamic Kindergarten, Baki, Sukoharjo, to find out the ability to listen to group A children. From observations made by researchers in cycle one through two meetings with quite increased results. These observations were conducted by researchers and assisted by an observer (to colleagues) at the time of the observation of learning activities with learning steps of the cycle of meetings with 25 children.

The results of observing children in the first cycle of meeting one are as follows: the ability to listen to children "The Story of the Prophet Ismail ": (a) BB (Not yet Developed) there are 14 children; (b) MB (Starting to Develop) there are six children; (c) BSH (Developing according to Hope) there are two children; (d) BSB (Very Good Development) there are three children. The process of listening to the screening of "The Story of the Prophet Ismail" has not been optimal. Activity when listening to children is still deficient. They prefer to play with friends. Following is the percentage of children's listening abilities in the first cycle of the first meeting:

\section{Graph 1: Percentage of Ability to Listen to Children on Screening "The Story of the Prophet Ismail"}

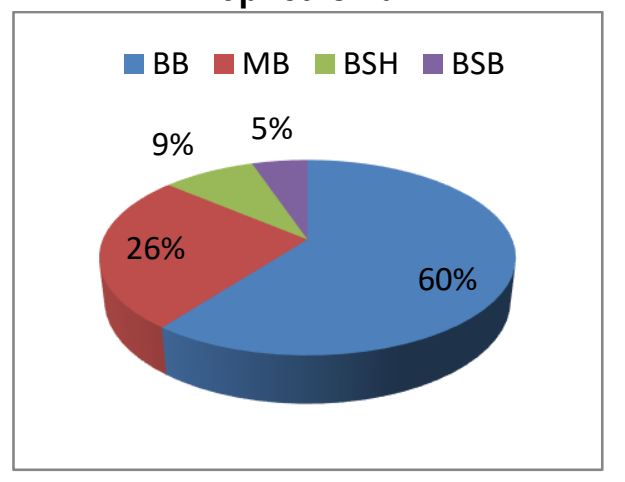


Karennina Cahya, Ruli Hafidah, Retnu Sipparamita / Improved Ability to Listen to Children of Group A in Al A'raaf Islamic Kindergarten Through Audio Visual Media

In the second cycle of meeting one, they aired a fairy tale entitled "Greedy Witches." Moreover, an animation about "The Importance of Eating Vegetables" was shown. The results of observations of children in the first cycle of meeting two are as follows: (a) BB (Not yet Developed) there are five children; (b) MB (Starting to Develop) there are four children; (c) BSH (Developing in Expectations) there are 12 children; (d) BSB (Very well developed) there are four children. The listening process at the second meeting of the children's listening activity increases as they tend to pay attention to the video being aired.

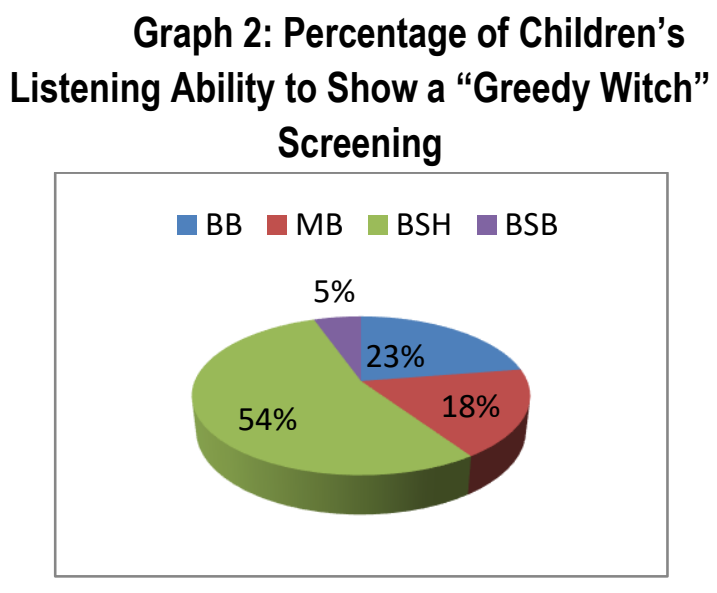

In cycle one of meeting two, children are in the audio area and are shown an animation about vegetables, "The Importance of Eating Vegetables". At the meeting, the two children showed improvement in their listening abilities. They look focused on video viewing. And the following observations are obtained: (a) BB (Not yet Developed) there are two children; (b) MB (Starts Developing) there are three children; (c) BSH (Develops as Expected) there are 15 children; (d) BSB (Very Good Developing) there are five children.

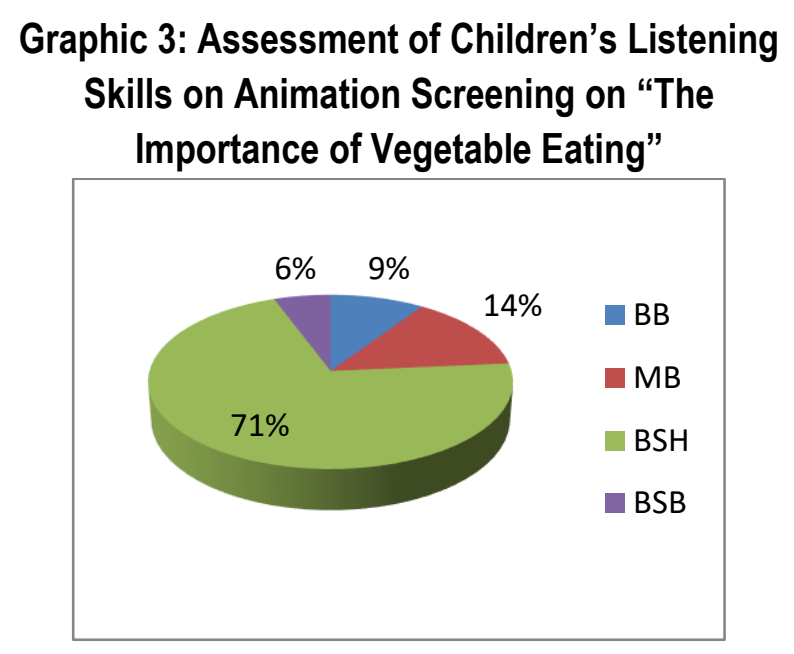

Information:

1. Children can answer simple questions from the teacher

2. The child can mention the object or content of the video display again

3. Children can understand the words of the teacher.

\section{Discussion}

In this discussion, the researcher explains the research findings in improving listening ability through audio-visual media in children aged 4-5 years. Children's learning outcomes improve at the second meeting. At the first meeting, optimal results were not obtained by the research objectives. Because the presentation of the story at the first meeting does not give an impression on children. Children's ability to mention the objects contained in the story is categorized as starting to develop because the child is still guided by the teacher in mentioning the objects in the story. While children's ability to retell stories that have been heard is also still categorized as developing, the child is still guided in retelling the story. Next is the percentage increase in the ability to listen to children in Al A'raaf Islamic Kindergarten. 
Golden Age: Journal of Early Childhood Education, Volume 04 Nomor 01 (Juni 2020)

ISSN 2549-8371 | E-ISSN 2580-5843

Karennina Cahya, Ruli Hafidah, Retnu Sipparamita / Improved Ability to Listen to Children of Group A in Al A'raaf Islamic Kindergarten Through Audio Visual Media

\section{Table 1 Results of Improving the Ability to Listen to Children with BSH Indicators Through Audio-Visual Media}

\begin{tabular}{l|c|c|c}
\hline \multicolumn{4}{c}{ Video Views } \\
\hline & $\begin{array}{c}\text { Story of the } \\
\text { Prophet }\end{array}$ & Fairy tale & Animation \\
\hline Percentage & $9 \%$ & $54 \%$ & $71 \%$ \\
\hline
\end{tabular}

The learning strategy through audio-visual media with video broadcasts is one of the widely used strategies in kindergarten learning, as with other teaching activities, the activity always starts by planning, implementing, and evaluating teaching activities. In the first cycle of the meeting I, children's ability to mention the objects they have seen, only about $9 \%$ of children with indicators develop according to teacher expectations. This is because the contents of these shows are less attractive to children.

In cycle one of meeting II, the ability to name objects or things they captured increased to $71 \%$ from the previous one. So, for us, pay attention during the video. In the second meeting, the teacher recalled grouping A children in Al A'raaf Islamic Kindergarten about vegetables' pictures by the video show. They are very enthusiastic about answering questions. The recalling proved that the child's ability to listen was better than the first meeting.

According to (Windaviv, 2015), there is a positive impact of increasing interest in studying audio-visual equipment that can generate a pleasant atmosphere in the learning process. Audio-visual media make children do not get bored quickly but stimulate children to know more. There are many entertainment elements by the subject matter, so that it makes the child more like and interested in learning. Audio-visual media is part of the learning resources needed in the learning process at school because, through audio-visual media we can increase children's interest in learning during the teaching and learning process. The influence of audio-visual media to increase children's interest in group A in Al A'raaf Islamic Kindergarten.
Based on interviews with class $A$ teachers at Al-A'raaf Islamic Kindergarten, children in class A prefer animation and fairy tales. In learning in AlA'raaf Islamic Kindergarten class using area learning. One of them is the audio area. Where in this area, using audio-visual media to practice the ability to listen to children. The use of audio-visual media can not be separated from deficiencies. Therefore a teacher must provide many other media to support the process of listening to children.

\section{CONCLUSION}

Based on the results and discussion research, it can be concluded that the use of media audio can visually enhance children's listening skills in group $\mathrm{A}$ at Al-A'raaf Islamic Kindergarten with category BSH (Developing in Expectations). The type of story shown in the audio area at Al A'raaf Islamic Kindergarten also influences listening to children. It has evidenced in the display of three different types of stories that listening to children increases.

Specifically, the following conclusions can be drawn: Learning planning in enhancing the ability to listen to stories through audio-visual media in group A children in Al-A'raaf Islamic Kindergarten is categorized as "good", with the category having to determine the theme and sub-theme material according to their interests, attention, and assessment of children's abilities.

\section{REFERENCES}

Haryoko, S. (2009). Efektivitas Pemanfaatan Media Audio-Visual Sebagai Alternatif Optimalisasi Model Pembelajaran. Jurnal Edukasi@Elektro, 5(1), 1-10.

Ivanovich Agusta. (2014). Teknik Pengumpulan dan Analisis Data Kualitatif. Jurnal Studi Komunikasi Dan Media, 02(1998), 1-11.

Lexi, J., \& M.A., M. (2010). Metodologi Penelitian Kualitatif. In Metodologi Penelitian Kualitatif. 54-68.

MENTERI PENDIDIKAN DAN KEBUDAYAAN REPUBLIK INDONESIA. (2014). Standar Nasional Pendidikan Anak Usia Dini. Peraturan Menteri Pendidikan Dan Kebudayaan Republik Indonesia, 13. 
Golden Age: Journal of Early Childhood Education, Volume 04 Nomor 01 (Juni 2020)

ISSN 2549-8371 | E-ISSN 2580-5843

Karennina Cahya, Ruli Hafidah, Retnu S̄ipparamita / Improved Ability to Listen to Children of Group A in Al A'raaf Islamic Kindergarten Through Audio Visual Media

Nilamsari, N. (2014). Memahami Studi Dokumen Dalam Penelitian Kualitatif. Jurnal Wacana, 14(2), 177-181. 143-455-1-PB (1).pdf

Prasitnok, K., Bulacu, M., Shen, Z., Ye, H., Zhou, C., Kröger, M., Li, Y. Y., Fonner, E., Drph, J., Acid, P., Grunewald, F., Rossi, G., De Vries, A. H., Marrink, S. J., Monticelli, L., Jiang, J. W., Wang, J. S., Li, B., Mukherjee, A. K., ... Cho, K. (2017). Upaya Meningkatkan Kemampuan Menyimak Melalui Metode Bercerita Dengan Media Ritatoon Pada Anak Kelompok B Di Tk Pertiwi Japanan I Cawas Klaten Tugas. Journal of Physical Chemistry B, 8(1), 28$48 . \quad$ https://doi.org/10.1016/S00092614(00)00764-8

Prof. Dr. H. Warul Walidin AK., M., Dr. Saifullah, S. Ag., M. A., \& Tabrani. ZA, S. Pd.I., M.S.I., M. (2015). Metodologi Penelitian Kualitatif \& Grounded Theory (M. A. Masbur (ed.)).

Setyawan, F. H. (2016). Meningkatkan Kemampuan Berbahasa Anak Usia Dini Melalui Model Pembelajaran Audio Visual Berbasis Android. Jurnal PG-PAUD Trunojoyo, 3(2), 92-98.

Suhartati, T. (2013). Upaya Meningkatkan Keterampilan Menyimak Cerita Anak Melalui Media Animasi Audio Visual Di Kelas V. 106.

Tarigan, H. G. (2008). Membaca sebagai Suatu Keterampilan Berbahasa. Angkasa.

Utami, R. E., Balai, P., Provinsi, B., \& Tengah, J. (2013). PEMBELAJARAN BAHASA INDONESIA. 278-295.

Windaviv, S. (2015). Pengaruh Penggunaan Media Audio Visual Untuk Meningkatkan Minat Belajar Anak Di Kelompok B Tk Perwanida Rejoso Nganjuk. 1-6. 